\title{
Examining the Effects of Presentation Patterns, Orders, and Information Types in Investment Decision Making ${ }^{+}$
}

\author{
Luciana Spica Almilia, ${ }^{a b^{*}}$ Jogiyanto Hartono, Supriyadi, and ErtambangNahartyo ${ }^{\mathrm{b}}$ \\ ${ }^{2}$ Perbanas Banking and Business College, Indonesia \\ ${ }^{b}$ Faculty of Economics and Business, Universitas Gadjah Mada,Indonesia
}

\begin{abstract}
This study aims to investigate the existence of Belief Model (BAM) developed by Hogarth and Einhorn (1992) in investment decision making. Particulary, this study examined: the effects of presentation patterns, presentation orders, and information types (accounting or non-accounting information) in investment decision making. This study used laboratory experiment to test the hypotheses. Hypotheses were tested using $t$-test. This study showed a "judgement bias" that is a recency which the effect of presentation pattern is consecutive is higher than unconsecutively.
\end{abstract}

Abstrak: Penelitian ini menguji eksistensi Belief Adjustment Model (BAM) yang dikembangkan oleh Hogart dan Einhorn (1992) dalam pengambilan keputusan investasi. Secara khusus, penelitian ini bertujuan untuk menguji pengaruh pola-pola penyajian informasi; menguji pengaruh urutan penyajian informasi; dan menguji tipe-tipe informasi (informasi akuntansi atau informasi non-akuntansi) dalam pengambilan keputusan investasi. Metode eksperimen digunakan untuk menguji hipotesis-hipotesis dalam penelitian ini dengan menggunakan indepen sample ( $t$-test). Hasil penelitian menunjukkan bahwa "judgment bias," khususnya efek kekinian akan lebih tinggi ketika pola penyajian informasi bersifat berurutan.

Keywords: end-of-sequence; investment judgment; order effect; primacy effect; recency effect; step-by-step

+ The earlier version of the paper is a part of Almilia's disertation on Accounting Department at Universitas Gadjah Mada, Indonesia.

* Corresponding authors. E-mail: almilia_spica@yahoo.com 


\section{Introduction}

Corporate disclosure is very important for investors in assessing a company's performance. Some researchers have already examined the benefit of annual reports (Abdelkarim et al. 2009; Alattar and AlKhater 2007) and the implementation of corporate governance reports (Hodge 2003; Sharma 2006) in order to rely on the information for their investment decision-making processes. It means that there is accounting and nonaccounting information needed for investment decisions.

The factors that may affect the investment decisions can be described in a model of the belief up-dating process. Bayes' Theorem is a revised model that was dominant in normative beliefs before 1988. It became popular as a consequence of the logic of conditional probabilities in belief revision. However, research in psychology and behavioral decisions has found that normative models e.g., Bayes' Theorem, do not adequately describe the belief-updating process as they cannot predict the intuitive revision (Ashton and Ashton 1988, and Kahle et al. 2005).

Some studies suggest that the discrepancy was due to the revision of the intuitive tendency that is driven by the characteristics of the task, such as the order of information presentation, which is not relevant to the normative model (Pitz et al. 1967 in Kahle et al. 2005). Recent psychology and behavioral accounting studies find that information order can affect individual belief revision process (e.g., Hogarth and Einhorn 1992; Ashton and Ashton 1988; and Kennedy 1993). More precisely, when mixed information (positive and negative) is received sequentially, the more recently received infor- mation is given more weight (Ashton and Ashton 1988). Krishnamoorthy et al. (1999) tested four theoretical models of belief revision, including a version of Bayesian inference. Krishnamoorthy et al. (1999) found that the model of Hogarth and Einhorn Belief Adjustment (1992) are the only models that capture the direction and magnitude of the auditor belief revision.

The study uses a model of Hogarth and Einhorn Belief Adjustment (BA) in making investment decisions that had been made by Pinsker (2007). Pinsker (2007) concludes that when a set of short series information consistently positive (negative) receive sequentially, compared to simultaneous disclosure, belief revision on the pricing of the stock price is significantly larger (smaller) in the sequential condition. Some studies of the order effect in making investment and business decisions have also been conducted by Tuttle et al. (1997), Baird and Zelin II (2000), Jogiyanto (2004), Guiral-Contreras et al. (2007), Pinsker (2007), and Pinsker (2011).

Stock transactions made by investors can not only be done after the annual report is published by the company. When investors receive incomplete information, their ability to derive proper firm valuation is hampered since incomplete information increases investor uncertainty as the annual reports are based on past information (previous annual reports) and/or on quarterly interim financial statements that are published by the company. Investors are demanding more timely firm disclosures in order to guide their decisionmaking processes. Based on the common practice mentioned previously, the researcher then conducted a thorough investigation on the information order obtained by the investor. 
The information orders that are tested in this study are a step-by-step (SbS) and the end-of-sequence (EoS). The pattern step-by-step $(\mathrm{SbS})$ is a pattern of presentation of information when investors had the transaction based on shared simple information (eg, financial statements and the quarterly interim non-accounting information obtained from the mass media) and performed in sequence. The end-of-sequence (EoS) is a pattern of presentation of information when investors had the transaction based on complete information and the whole reports obtained at such particular time lines (for example: complete annual report which does not only contain financial statements).

Some studies show that when information orders are received at the end-of-sequence, recency effects will not be potential for decision making process (Pinsker 2007). This study has been conducted to examine the effect of the order and pattern of information and to find out the reason why the recency effect occurs at the step-by-step sequence of disclosures. The answers will be found by testing the contrast or anchoring effect as Belief adjustment (BA) can identify the impact of a decision-maker's sensitivity toward positive and negative information on the magnitude of belief revision. It prescribes that the strength of the anchor through a "contrast" effect such that high anchors are "hurt" more than smaller ones by the same negative evidence. Based on this phenomenon and the background of the problem, the main focus of this study thus, is to test Belief Adjustment model developed by Hogarth and Einhorn (1992) for making investment decisions.

\section{Theory and Hypotheses}

\section{Information - Order Effect and Business Reporting Models}

Ideally, an investor or manager should focus on the facts rather than looking at the information order or model of the report, so that the belief or conclusion can be drawn based on the substance of the evidence. The information order may affect belief or decision when an investor or manager or an individual makes belief revision after receiving evidence of a different order or after considering additinal information. The information order has mixed facts in which good news or positive information is received sequentially with bad news or negative information. Primary effect (first effect) occurs if the initial information in the sequence has the greatest influence on individual beliefs while the recency effects is the final belief of an individual which is affected more by information received later (more recently) than that received earlier (regardless of whether the information processing task is simple or complex).

Ashton and Ashton (1988) and Tubbs et al. (1990) show that there will be no recency effect if the proof obtained is either consistently positive or consistently negative. In contrast, the recency effect occur if the evidence, that are evaluated, have formed a mixed union which are positive and negative.

The phenomenon of the order effect occurs when the people evaluate new evidence, and adjustment of the duty is based on insufficient additional evidence. Hogarth 
and Einhorn (1992) adopt a general concept of the belief-adjustment including bias that may happen and form a psychological framework known as the belief-adjustment model. The model provides recency predictions when an individual evaluates mixed or complex information received (negative or positive). Evidence of a short series consists of a maximum of 12 items. The complexity is associated with familiarity with the task and the length of the items of the information. Mixed or combined information is the evidence consisting of positive and negative information.

Bamber et al. (1997) provide strong support for the validity of the belief adjustment model. The belief adjustment model can predict the effects sequences in all case response models (step-by-step or end-of-sequence respond mode), task complexity and length information. Some individual investors are easily influenced by the evidence (evidence prone). Investors are looking at the stock market as a basis for their investment decisions. The number of the investors that are seeking information is indicated by the rapid growth of business-related information used by media companies (e.g. the company's website), and by the number of investors who need timely information.

Tuttle et al. (1997) examine the effect of sequence on the efficiency of the market and conclude that individual investors are experiencing the effects of the present when they received four clues/combined evidence. Hogarth and Einhorn's model (1992) predicts that the individual encodes or processes information on his/her subsequent judgment which is affected by encoding variables of processing mode known as Step-by-step (SbS) response model or sequential users tend to find any recency effect. The phenomenon of recency effect is also supported in the study done by Messier (1992). Messier (1992) provides evidence that staff auditors who received complex and diverse evidence (positive and negative information) with the pattern of sequential information presented will encounter the recency effect.

Asare (1992) also provides similar evidence of the emergence of recency effect on managers and in auditors' going-concem judgments with the pattern of sequential information presenting (step-by-step). It is also shown by Tubbs et al. (1993) that recency effect will appear when the individual receives inconsistent evidence when a step-by-step response mode (i.e., decisions are revised after receiving each incremental piece of information) is applied, although individuals have been given training to accomplish the task. The argument of order effect in related to the pattern of information presenting (stepby-step) is also supported by McMillan and White (1993), Ahlawat (1999), Baird and Zelin II (2000); Monroe and Ng (2000), and Guiral-Contreras et al. (2007).

Hogarth and Einhorn's model (1992) predicts that the decision made after each piece of evidence is obtained (response model step-by-step/SbS) tend to receive any influence of the order, while a decision made after all the evidence is received (response model end-of-sequence/EoS) is unlikely to have recency effect. EoS can reduce the recency because the contradiction influence given by the information presented in several phases. It can be eliminated by combining the effects of positive and negative evidences, so that it would eliminate the individual effect of negative and positive evidence. Pinsker (2007) indicates that more confidence adjustment to disclose the information presented one by one (sequentially) than those of concurrent (simultaneous) either after or before the first 
series of consistent information (information short series).

According to the BA model, an individual's sensitivity plays a large role in determining the magnitude of belief revision, for example when mixed information (positive and negative) is received sequentially, the information order effects can be: recency effect and primacy effect, whereby in the primacy effect the final belief of an individual is affected more by information received earlier than that received later (more recently). Primacy effect is also known as attention decrement effect: recent information received is considered more than that of the first (earlier). Primacy effect is due to the limitations of the individual to process the information he/she receives so that when new information comes, he/she would like to consider first information rather than the most current one.

Recency effect was also found in the studies of professional auditors (Ashton and Ashton 1988). Ashton and Ashton (1988) provide evidence that the auditors are more sensitive to recent evidence when they are given the evidence in the order of combined sequence $[++$ - - (good news followed by bad news) or - - ++ (bad news followed by good news)]. The recency effect in this case can be explained by the contrast effect which elaborates that high anchor is more sensitive to negative evidence than low anchor. Conversely, a low anchor is more sensitive to positive evidence than the high anchor.

Jogiyanto (2004) provides evidence that from his four hypotheses of recency, only negative dividend surprise effect is not proved. It can be inferred that the sequence of negative dividend surprise is not important.
Hogarth and Einhorn's belief adjustment model (1992) predicts that step-by-step information framing will create recency effect either in simple or complex information. The end-of-sequence pattern will only create primacy effect on a simple information and recency effect will appear within complex information.

This study is trying to examine the effect of order and pattern of information presentation by using three types of information: the accounting information, non-accounting information, and the combination of nonaccounting and accounting information toward bias investment decisions. The research hypotheses are;

$H_{1 a}:$ Subject who are provided with positive and then negative items (the order was ++ --) will give lower judgment on the company's stock compared to subjects who receive the information in the order of -- ++ on the sequential presentation pattern of all the information (accounting, non-accounting, and combination of non-accounting and accounting information).

$H_{16}$ : Subjects who receive the information in the order of ++ -- will give the same judgment on the company's stock and those who received the information in -- ++ order, on the pattern and the simultaneous presentation of simple information.

\section{Methods}

\section{Subject of the Research}

Criteria for subjects participating in the study are: Each participant possesses knowledge in the field of investment, capital markets, and financial reporting analysis Based on these criteria, the subjects in this study include: accounting and management students 
who are knowledgeable in the field of investment, capital market analysis, and financial statements.

The subjects were requested to respond to eight (8) multiple choice questions related to their capabilities in the areas of investment and capital markets and financial statement analysis. Their capabilities in those areas were tested to determine that the differences in their basic skills in the areas of investment and capital market analysis and financial statements do not affect their decisions making.

Treatments were given in relation to (1) the pattern of information presentation (stepby-step, and end-of-sequence), (2) the presentation order $(++--$ or -- ++$)$, (3) Type of information (accounting, non-accounting, and combined accounting information and non-accounting).

\section{Experiment Design}

This study uses an experiment method to test the causal relationship between the variables that are manipulated to answer the research problem. It was chosen because the method can control the tested variables and confounding variables that affect the causal relationship. A $2 \times 2 \times 3$ experimental design is used to test the research hypotheses. It is a mixed design (between and within subjects), including (1) the pattern of information presentation (step-by-step and the end-of-sequence), (2) the presentation order or sequence $(++--$ or -- ++$)$ is the sequence of positive information/good news followed by negative information/bad news or otherwise, and (3) accounting information, non-accounting information, and combined accounting and non-accounting. Between subject design is compared to the stock assessment between the two groups of subjects who received pre- sentation pattern (step-by-step and the endof-sequence) and sequence of presentation $(--++$ and ++--$)$. The objective within subject design in this research is examined different responds of the subject treatments on those three accounting information.

The independent variables are: (1) the pattern of information presentation (step-bystep and the end-of-sequence), (2) the presentation sequence $(++--$ or -- ++$)$ the sequence of positive information/good news followed by information negative/bad news or otherwise, (3) Type of information (accounting, non-accounting, and combined accounting and non-accounting).

The subjects were divided into several groups. The grouping is related to the pattern of presentation of information (step-by-step, the end-of-sequence, and self-review debiaser), the order of presentation $(++--$ or -- ++ ), and the type or types of performance measurement information (financial statements are common performance measures; non-financial reporting the company is a specialized performance measurement, and a comprehensive report comprises of the financial statements and non-financial performances).

\section{Task and Procedure}

The researcher used web based facilities in which the subjects were asked to visit a particular interactive website that had been designed by the researcher. When the subjects open the address, they had some treatments and were asked to answer questionnaire related to stock price decision based on each treatment given at random.

Then their tasks were to assess stock value of the company PT. ABC which was only a hypothetical (imaginary) company but it was taken from real example of companies 
that are listed on the Indonesian Stock Exchange. In the initial phase, the subject received background information on the company and the initial value of the company's stock was determined by Rp1,900.00 as a reference value.

The subjects were asked to reassess the value of the investment for each type of information and the pattern of information presentation (step-by-step, end-of-sequence and self-review debiaser) with initial value shares Rp1,900.00 and provide scale for each disclosure with multiple prices - 100 (very bad news) and +100 (very good news). After reading and responding to disclosure items, the subjects responded to manipulation check questions, inquiries psychological experiment (to measure the characteristics of overconfident), questions to measure participants' basic skills in the field of analysis of financial statements and capital markets, and respondent demographic items.

Especially for the subjects in the stepby-step (SbS) category were divided into two sub groups, namely high anchor and low anchor for any kind of accounting information. High anchor in this study has the initial value of the company's stock price Rp1,900.00 while a lower anchor has Rp1,900.00.

Manipulation checks were conducted to find out whether the subjects have understood and responded correctly to the given. The first one was given to determine the increase/decrease of the company's stock price which should be the multiple of 100 , if the subject did not give the multiples of 100 ; he or she was declared failure in the first manipulation. Subjects who failed in the manipulation check were not allowed to do further analysis.

The second manipulation check in this research was done by giving three (3) questions about each piece of information, so total manipulation questions are 9 (nine). These questions were given to assess comprehension, attention and seriousness of the subjects on the experiments. Nine questions had equal weight. The subject was successful if he/she answered correctly 5 out of 9 questions and he/she got reward Rp25,000.00 - Rp75,000.00. It signifies that he/she had already known, understood and given correct respond of given assignment. The purpose of the reward Rp25,000.00 - Rp75,000.00 is to encourage participants to follow the experiment in accordance with the schedule and to appreciate their participation in this experiment.

\section{Data Analysis}

Hypothesis 1a and Hypothesis1b were tested by using independent sample $t$ test. Hypothesis 1a was tested by comparing the final judgment of participants who received information in the order of ++ -- compared to participants who received a final judgment with information order -- ++ , for the presentation of sequential pattern/step-by-step. Hypotheses $1 \mathrm{~b}$ was tested by comparing the final judgment of participants who received information sequence ++ -- compared to participants who received a final judgment order information -- ++ , for the simultaneous presentation of pattern/end-of-sequence.

\section{Demographic Data and Manipulation Check}

The number of subjects is 43 participants. Twenty-eight (28) of them have not filled up the instrument within the specified time limit, and there are 11 subjects that cannot be analyzed any further because they do not pass the manipulation check. The total number of subjects who can be used for further process of the experiment is 43 partici- 
Table 1. Number of Eligible Participants

\begin{tabular}{lc}
\hline Remarks & Total \\
\hline Number of participants who are willing to participate. & 82 \\
Number of participants who do not fill in the instrument & 28 \\
Number of participants who have filled in the instrument & 54 \\
Number of un-illegible participants & 11 \\
\hline Number of participant who are eligible for the research & 43 \\
\hline
\end{tabular}

Table 2. Number of Participants based on Experiment Scenario

\begin{tabular}{cllc}
\hline Scenario & $\begin{array}{c}\text { Type of Reporting } \\
\text { Information }\end{array}$ & Sequence & Total Participants \\
\hline 1 & Step-by-Step & ++-- & 10 \\
2 & Step-by-Step & --++ & 12 \\
3 & End-of-Sequence & ++-- & 11 \\
4 & End-of-Sequence & --++ & 10 \\
\hline & Total: & & 43 \\
\hline
\end{tabular}

pants. The data on the number of eligible participants who are willing and able to be used by students and practitioners of the subject groups are presented in Table 1

Table 2 exhibits information on the distribution of the subjects that are divided into 4 types of scenario: 10 people are in scenario 1; 12 people are in scenario 2; 11 people are in scenario 3; 10 people are in scenario 4 .

\section{The Effect of Sequence and Disclosure Pattern on the Investment Decision}

Hypothesis $1 a$ is postulated to test whether all kinds of information (accounting, non-accounting, combination of nonaccounting and accounting information), will assess lower on company's stock when they receive information in the order of ++ -(good news followed by bad news) than when they receive information in the order of -++ (bad news followed by good news). Table 3 summarizes the results of Hypothesis 1a testing.

The Belief adjustment model of Hogarth and Einhorn (1992) predicts that the step-by-step presentation pattern will create a recency effect when the information is both complex and simple. The empirical data in this study support the model. The results of the research confirm the findings of previous studies that the recency effect phenomenon will occur if the pattern of information disclosure is in sequential (step-by-step) on the investment decision-making and auditing. In 
Table 3. The results Summary of Hypothesis 1a Testing

\begin{tabular}{lccccc}
\hline $\begin{array}{c}\text { Information } \\
\text { Types }\end{array}$ & Evidence Order & Mean & Results & t-stat & Sig. \\
\hline All information & ++-- & $15,493.3333$ & Recency Effect & -6.171 & 0.000 \\
& --++ & $21,136.1111$ & & & \\
Accounting & ++-- & $14,450.0000$ & Recency Effect & -4.515 & 0.000 \\
& --++ & $21,758.3333$ & & & \\
Non-accounting & ++-- & $16,660.0000$ & Recency Effect & -2.972 & 0.008 \\
& --++ & $21,200.0000$ & & & \\
Accounting and & ++-- & $15,370.0000$ & Recency Effect & -3.063 & 0.006 \\
Non-accounting & --++ & $20,450.0000$ & & & \\
\hline
\end{tabular}

auditing, for example, this study confirms the results of Messier's research (1992) which provides evidence that staff auditors who received the information or evidence in a complex and sequentially diversified pattern (positive and negative information), will have recency effect. Asare (1992) also confirms similar evidence of the emergence of recency effect on managers and related audit partner's judgment going concern when evidence was presenting sequentially (step-by-step). This study confirms other research findings conducted by Pinsker (2007) which shows recency effect on the pattern of presentation compared to a step-by-step presentation at the end-of-sequence on the investment decision.

The findings of this study indicate particular bias on judgment particularly recency effect which becomes greater and greater if the pattern of information is reviewed consecutively. The findings are very important, because in practice the capital market or investors also use the same pattern in making investment, which of course will result in a bias in decision-making.

A different sequence of information affects an investor, which means that the same information given in a different order may result in different considerations. The results of this study show that belief revision depends on the sequence and pattern of presentation of the information. It has an impact on the quality of investment decisions based solely on the last information received, and when the last update is of inferior quality, of course, it has an impact on the quality of the investment decision-making.

The results of this study indicate that investors make a greater belief revision on the sequentially presented information. The reason is the presentation of information in a sequence (SbS) provides more opportunities to the investors to make adjustments, and do excessive adjustments (over adjust) toward each item. The excessive adjustment raises the recency effect.

Hypothesis $1 \mathrm{~b}$ was addressed to test whether subjects will rate the company's shares with the same judgement after receiving the information in the order ++ -- and when the information in the order -- ++ the simultaneous presentation of the pattern (the 
Table 4. Summary of Hypothesis $1 \mathrm{~b}$ Testings (Information Disclosure Type: End-ofsequence)

\begin{tabular}{lccccc}
\hline $\begin{array}{l}\text { Information } \\
\text { Types }\end{array}$ & Evidence Order & Mean & Results & t-stat & Sig. \\
\hline All information & ++-- & $18,354.5454$ & No Recency Effect & -0.369 & 0.713 \\
& --++ & $18,710.0000$ & & & \\
Accounting & ++-- & $18,427.2727$ & No Recency Effect & -0.884 & 0.388 \\
& --++ & $20,150.000$ & & & \\
Non-accounting & ++-- & $18,627.2727$ & No Recency Effect & 1.398 & 0.178 \\
& --++ & $16,790.0000$ & & & \\
Accounting and & ++- & $18,009.0909$ & No Recency Effect & -0.709 & 0.487 \\
Non-accounting & --++ & $19,190.0000$ & & & \\
\hline
\end{tabular}

pattern of presentation EoS) and simple information. Table 4 summarizes the results of testing Hypothesis $1 \mathrm{~b}$.

The results showed that when the information received is only the accounting information and non-accounting, there was no difference in the final judgment when the sequence of information is ++-- or -- ++ at the end of the presentation of pattern sequences. The results of this study support the research Trotman and Wright (1996), Ashton and Kennedy (2002), and Pinsker (2007) that the recency effect does not occur at the end of sequential presentation pattern and simple information.

The test results showed no significant difference in the average final judgment for the subjects who received information ++-compared to subjects who received information -- ++ on student participants. It showed consistent results that there is no significant difference in the average final judgment for the subjects who received information ++ -compared to subjects who received information -- ++. The results of this study indicate that the pattern of presentation of the EOS does not cause primary effect and recency effect on student participants both when the information received is accounting, non-accounting or a combination of accounting information and non-accounting.

The findings of this study had bias judgment particularly recency effect occurrence if the information was presented in a complex form. The findings are very important, because in practice, investors or capital market practitioners face a wide range of information that includes not only financial performance information but also other non-financial information which of course will impact on the judgment complexity. In turn, it will create bias judgment because of the diversity of the information presented to the company's stakeholders.

\section{Summary}

Based on the results of hypothesis testing and the discussion, the findings of this study indicate a particular bias judgment particularly a recency effect that becomes greater if the review information pattern is made consecutively. The findings are very important because in practice the investors use the same 
review pattern, which of course will result in a bias in decision-making.

The theoritical implication of this research is that the study provides empirical evidence of the importance of the information complexity factor in making investment decisions. Previous research did not compare comprehensively the role of information in the Belief Adjustment model of Hogarth and Einhorn in a variety of information- presentation patterns.

The experimental design used in this study always faced the trade-off between internal and external validity. In addition to such a compromise, this study cannot be separated from the other limitations. Experimental material in this study did not include familiarity level of information -information used in making investment decisions, though in this study the researcher used accounting and nonaccounting information.

Based on the findings, conclusions and limitations in this study, there should be more research in the future. First, the future studies may use different information, not only about the fundamental information. In practice, in making investment decisions the investors do not only need fundamental analysis but also uses technical analysis, and information regarding the economy condition of a country. Future studies may consider those aspects in testing the model of Hogarth and Einhorn Belief Adjustment.

\section{References}

Abdelkarim, N., Y. A. Shahin, and B. M. Arqawi. 2009. Investor perception of information disclosed in financial reports of Palestine securities exchange listed companies. Accounting and Taxation 1 (1): 4561.

Ahlawat, S. S. 1999. Order Effect and Memory for Evidence in Individual versus Group Decision Making in Auditing. Journal of Behavioral Decision Making 12: 71-88.

Alattar, J. M., and K. Al-Khater. 2007. An empirical investigation of users' views on corporate annual reports in Qatar. International Journal of Commerce and Management 17 (4): 312-325.

Asare, S. K. 1992. The auditor's going-concern decision: Interaction of task variables and the sequential processing of evidence. The Accounting Review 67 (2): 379-393.

Ashton, A. H., and R. H. Ashton. 1988. Sequential belief revision in auditing. The Accounting Review 64 (4): 623-641.

Baird, J. E., and R. C. Zelin II. 2000. The effects of information ordering on investor perceptions: An experiment utilizing presidents' letters. Journal of Financial and Strategic Decisions 13 (3): 71-80.

Bamber, E. M., R. J. Ramsay and R. M. Tubbs. 1997. An Examination of the descriptive validity of the belief-adjustment model and alternative attitude to evidence in auditing. Accounting, Organizations and Society 22: 249-268.

Guiral-Contreras, A., J. A. Gonzalo-Angulo, and W. Rodgers. 2007. Information content and recency effect of the audit report in loan rating decisions. Accounting and Finance 47: 285-304.

Hodge, F. D. 2003. Investors' perception of earnings quality, auditor independence, and the usefulness of audited financial information. Accounting Horizons 17: 37-48 
Hogarth, R. M., and H. J. Einhorn. 1992. Order effect in belief updating: The belief - adjustment model. Cognitive Psychology 24: 1-55.

Jogiyanto. 2004. Psychology of Finance: How, Why and When Investor Revise their Beliefs to Company Information and their Implocations to Firm's Announcement Policy. Yogyakarta, Indonesia: Penerbit Andi.

Kahle, J., R. Pinsker, and R. Pennington. 2005. Belief revision in accounting: A literature review of the belief-adjustment model. Advances in Accounting Behavioral Research 8: 1-40.

Kennedy, J. 1993. Debiasing audit judgment with accountability: A framework and experimental result. Journal of Accounting Research 31: 231 - 245.

Krishnamoorthy, G., T. J. Mock, and M. T. Washington. 1999. A comparative evaluation of belief revision models in auditing. Auditing: A Journal of Practice and Theory 18: 143-153.

McMillan, J. J., and R. A. White. 1993. Auditors' belief revisions and evidence search: The effect of hypothesis frame, confirmation bias, and professional skepticism. The Accounting Review 68 (3): $443-$ 465.

Messier, W. F., and R. M. Tubbs. 1994. Recency effect in belief revision: The impact of audit experience and the review process. Auditing: A Journal of Practice and Theory 13 (1): 57-72.

Monroe, G. S., and J. Ng. 2000. An examination of order effect in auditors' inherent risk assessments. Accounting and Finance 40: 153-168.

Pinsker, R. 2007. Long series of information and nonprofessional investors' belief revision. Behavioral Research in Accounting 19: 197- 214.

Pinsker, R. 2011. Primary or recency? A study of order effects when nonprofessional investors are provided a long series od disclosures. Behavioral Research in Accounting 23 (1): 161-183.

Sharma, D. S. 2006. Effects of professional and non-professional investors' perceptions of board effectiveness on their judgments: An experimental study. Journal of Accounting and Public Policy 25: 91115.

Tubbs, R. M., W. F. Messier, and W. R. Knechel. 1990. Notes: Recency effect in the auditor's belief revision process. The Accounting Review 65 (2): 452- 480.

Tuttle, B., M. Coller, and F. G. Burton. 1997. An examination of market efficiency: information order effects in a laboratory market. Accounting, Organizations and Society 22 (1): 89- 103. 